\title{
PENGARUH PROFITABILITAS, LEVERAGE DAN KEBIJAKAN DIVIDEN TERHADAP NILAI PERUSAHAAN PROPERTI, REAL ESTATE DAN KONSTRUKSI BANGUNAN
}

\author{
Putu Diah Melinda Yanti ${ }^{1}$ \\ Nyoman Abundanti ${ }^{2}$ \\ ${ }^{1}$ Fakultas Ekonomi dan Bisnis Universitas Udayana, Bali, Indonesia \\ email:diahmelinda@yahoo.com
}

\begin{abstract}
ABSTRAK
Penelitian ini dilakukan untuk menguji pengaruh profitabilitas, leverage dan kebijakan dividen terhadap nilai perusahaan di perusahaan sektor property, real estate dan konstruksi bangunan di Bursa Efek Indonesia yang secara berturut-turut membagikan dividen pada periode 2014 sampai dengan 2017. Jumlah sampel yang diteliti sebanyak tiga belas (13) perusahaan yang dipilih melalui metode purposive sampling yang menentukan kriteria tertentu dalam menentukan sampel yang akan digunakan pada periode pengamatan selama empat tahun. Metode pengumpulan data yang digunakan dalam penelitian ini adalah dengan metode observasi nonpartisipan, yaitu dengan mengamati laporan keuangan perusahaan. Analisis data dilakukan dengan teknik analisis regresi linier berganda. Berdasarkan hasil analisis ditemukan bahwa profitabilitas dan leverage berpengaruh positif signifikan terhadap nilai perusahaan, sedangkan kebijakan dividen berpengaruh negatif tidak signifikan. Hal ini menandakan kebijakan dividen bukan merupakan salah satu faktor utama yang mempengaruhi nilai perusahaan.
\end{abstract}

Kata kunci: nilai perusahaan, dividen, profitabilitas, leverage

\section{ABSTRACT}

This study was conducted to examine the effect of profitability, leverage and dividend policy on the value of companies in property, real estate and building construction companies on the Indonesia Stock Exchange which distributed dividends in a period between 2014 and 2017. Thirteen samples were examined. (13) companies selected through purposive sampling method that determines certain criteria in determining samples to be used in the observation period for four years. The data collection method used in this study is a nonparticipant observation method, namely by observing the company's financial statements. Data analysis was done by multiple linear regression analysis techniques. Based on the results of the analysis it was found that profitability and leverage had a significant positive effect on firm value, while dividend policy had a negative and insignificant effect. This indicates that dividend policy is not one of the main factors affecting the value of the company.

Keywords: company value, dividend, profitability, leverage 


\section{PENDAHULUAN}

Perkembangan pasar modal di Indonesia mengalami pertumbuhan yang pesat. Otoritas Jasa Keuangan (OJK) mencatat dana yang terhimpun dari interaksi di BEI meningkat 24 persen dari tahun sebelumnya dan mencapai 276,5 triliun rupiah yang melampaui target awal sebesar 217 triliun rupiah (www.bisnis.com). Hal ini menunjukkan pasar modal semakin menarik sebagai alternatif sumber pembiayaan. Karena itu persaingan antar perusahaan dalam memperoleh pembiayaan akan semakin ketat. Terbukti dengan banyaknya perusahaan yang melakukan Initial Public Offering (IPO) saham di BEI. Tahun 2018 setidaknya ada 26 perusahaan yang berencana melakukan IPO. Oleh karena itu perusahan harus mampu menunjukkan kinerja terbaik untuk dapat bersaing.

Tujuan utama dari manajemen keuangan adalah mensejahterakan pemegang sahamnya. Pemegang saham merupakan pemilik dari perusahaan yang memberikan wewenang kepada manajemen untuk menjalankan operasi atau pengelolaan terhadap perusahaan (Hartono, 2016). Manajemen diharapkan mampu membawa perusahaan pada kinerja yang baik sehingga dapat meningkatkan nilai perusahaan dan bermuara pada kesejahteraan pemegang saham.

Adapun bentuk kinerja suatu perusahaan tidak terlepas dari perencanaan yang di dalamnya terdapat berbagai tujuan perusahaan yang direncanakan, baik dalam jangka panjang maupun jangka pendek. Tujuan utama dari setiap perusahaan adalah memaksimalkan laba, mengusahakan pertumbuhan dan menjamin kelangsungan hidup perusahaan. Tujuan perusahaan jangka pendek yaitu mendapatkan laba maksimal dengan sumber daya yang ada, sedangkan dalam jangka panjang tujuan utama perusahaan adalah memaksimalkan nilai perusahaan. Nilai perusahaan dapat memberikan pengaruh terhadap persepsi investor, karena nilai perusahaan akan menggambarkan kinerja dan keadaan perusahaan. Bagi perusahaan yang belum go public nilai perusahaan merupakan sejumlah biaya yang bersedia dikeluarkan oleh calon pembeli jika perusahaan tersebut dijual, sedangkan bagi perusahaan yang sudah go public nilai perusahaannya dapat dilihat dari besarnya nilai saham yang ada di pasar modal (Husnan, 2013).

Investor tertarik terhadap suatu perusahaan dapat terjadi karena informasi yang disampaikan dalam rasio keuangan, dimana rasio keuangan ini diperoleh setelah dilakukannya analisis terhadap laporan keuangan perusahaan. Rasio keuangan yang menunjukkan bahwa perusahaan memiliki prospek yang baik di masa depan akan memberikan nilai tambah bagi perusahaan di mata investor. Fenomena laporan keuangan yang dipublikasikan menunjukkan peran dari signaling theory. Signaling theory didasarkan pada asumsi bahwa informasi yang diterima oleh masih - masing pihak tidak sama. Signaling theory menunjukkan adanya asimetri informasi antara manajemen perusahaan dengan pihak - pihak yang berkepentingan terhadap informasi. Pihak - pihak yang berkepentingan perlu diberikan informasi melalui penerbitan laporan keuangan. Signaling theory mengemukakan tentang bagaimana seharusnya sebuah perusahaan memberikan sinyal kepada pengguna laporan keuangan. Menurut Wiagustini (2014:7) nilai perusahaan dapat dipengaruhi oleh keputusan manajemen keuangan meliputi keputusan pendanaan, keputusan investasi, serta keputusan dividen. Keputusan investasi adalah keputusan keuangan yang berkaitan dengan aktivitas investasi 
dalam berbagai bentuk. Keputusan pendanaan merupakan keputusan keuangan yang berkaitan dengan aktivitas pembelanjaan atau pembiayaan investasi. Keputusan dividen adalah aktivitas keuangan yang berkaitan dengan distribusi laba yang diperoleh perusahaan. Keputusan - keputusan yang diambil oleh manajer keuangan akan berpengaruh terhadap kinerja keuangan yang tercermin pada rasio keuangannya.

Penelitian ini menggunakan tiga rasio yang akan diteliti pengaruhnya pada nilai perusahaan. Ketiga rasio tersebut adalah profitabilitas, leverage, dan Dividend Payout Ratio (DPR) sebagai rasio untuk mengukur kebijakan dividen. Tiga rasio tersebut merupakan rasio internal perusahaan, kondisi internal perusahaan menggambarkan pengelolaan keuangan perusahaan tersebut. Penelitian mengenai pengaruh proftabilitas, leverage dan kebijakan dividen terhadap nilai perusahaan telah dilakukan sebelumnya, namun hasil yang tidak konsisten menyebabkan peneliti tertarik untuk menguji kembali pengaruh profitabilitas, leverage, dan kebijakan dividen terhadap nilai (Gayatri \& Mustanda, 2012).

Rasio pertama yang dapat mempengaruhi nilai perusahaan adalah profitabilitas. Profitabilitas merupakan tujuan utama sebuah perusahaan, maka dari itu profitabilitas dianggap penting dalam penelitian ini. Perusahaan yang berhasil membukukan laba yang meningkat, mengindikasikan perusahaan tersebut mempunyai kinerja yang baik, sehingga dapat menciptakan sentimen positif para investor dan dapat membuat harga saham perusahaan meningkat. Meningkatkan harga di pasar, maka akan meningkatkan nilai perusahaan. Profitabilitas yang tinggi menunjukkan prospek perusahaan baik, sehingga investor akan merespon positif dan nilai perusahaan akan meningkat. Begitupun sebaliknya, apabila perusahaan menunjukkan kinerja yang buruk maka akan menciptakan pandangan negatif dari para calon investor sehingga nilai perusahaan akan menurun. Rasio profitabilitas dalam penelitian ini diukur menggunakan Return on Equity ( $R O E$ ) karena $R O E$ mampu menunjukkan seberapa besar kontribusi ekuitas dalam menciptakan laba bersih, sehingga $R O E$ dapat menggambarkan seberapa efektif perusahaan mengelola modal yang diperoleh dari investor untuk menciptakan laba bersih.

Rasio lain yang mempengaruhi nilai perusahaan adalah leverage. Leverage adalah kemampuan perusahaan dalam memenuhi kewajiban jangka pendek maupun jangka panjang atau dengan kata lain mengukur seberapa besar perusahaan dibiayai dengan hutang (Wiagustini, 2014). Rasio leverage dalam penelitian ini diukur menggunakan Debt to Equity Ratio (DER) dimana DER menunjukkan perbandingan jumlah hutang dengan jumlah dana yang berasal dari pemilik perusahaan dalam membiayai kegiatan perusahaan. Penambahan penggunaan hutang akan memberikan pandangan positif, karena perusahaan yang meningkatkan penggunaan hutangnya dapat dipandang sebagai perusahaan yang yakin dengan prospek perusahaan di masa yang akan datang. Perusahaan yang menggunakan hutang untuk membiayai tujuan produktif justru akan bisa menghasilkan keuntungan di masa yang akan datang.

Kebijakan dividen juga dianggap sebagai faktor yang berpengaruh terhadap nilai perusahaan. Kebijakan dividen merupakan keputusan mengenai pembagian laba atau menahannya guna diinvestasikan kembali di dalam perusahaan (Brigham \& Houston, 2011). Bird in the hand theory menyatakan bahwa pemegang saham 
lebih menyukai dividen yang tinggi karena memiliki kepastian yang tinggi dibandingkan capital gain. Kebijakan dividen dapat dikonfirmasi dalam bentuk Dividend Payout Ratio (DPR). Dividend payout ratio adalah perbandingan dividen yang diberikan ke pemegang saham dan laba bersih per saham. Dividend Payout Ratio menentukan jumlah laba yang akan dibagi dalam bentuk dividen kas dan laba yang ditahan sebagai sumber pendanaan.

Kebijakan dividen dapat membawa pengaruh terhadap harga saham perusahaan. Adanya kenaikan jumlah dividen tunai menyebabkan perusahaan dianggap mempunyai prospek yang baik di masa depan. Kenaikan dividen tunai seringkali menyebabkan kenaikan harga saham yang berarti bahwa nilai perusahaan meningkat, sementara pemotongan dividen umumnya menyebabkan penurunan harga saham yang berarti penurunan nilai perusahaan.

Beberapa penelitian terdahulu mengenai pengaruh profitabilitas, leverage, dan kebijakan dividen masih menunjukkan ketidak konsistenan antara penelitian satu dengan penelitian lainnya. Chen \& Chen (2011), Wulandari (2013), Wahyuni dkk. (2013), Mahendra dkk. (2009), Sabrin et al. (2016), Andawasatya et al. (2017), dan Tui et al. (2017) dalam penelitiannya menyatakan bahwa profitabilitas berpengaruh positif terhadap nilai perusahaan. Hasil yang berbeda ditemukan oleh Herawati (2011) menyatakan bahwa profitabilitas berpengaruh negatif dan signifikan terhadap nilai perusahaan. Pratama \& Wiksuana (2018) juga menemukan bahwa profitabilitas berpengaruh negatif signifikan terhadap Nilai Perusahaan. Hal ini menunjukan, semakin besar profit yang diperoleh dari sebuah perusahaan tidak menjamin meningkatnya nilai dari perusahaan tersebut.

Penelitian yang dilakukan oleh Chen \& Chen (2011), Sambora dkk. (2014), Adenugba et al. (2016), serta Ishari \& Abeyrathna (2016) menemukan bahwa leverage berpengaruh negatif terhadap nilai perusahaan. Namun, penelitian yang dilakukan oleh Sudiyatno \& Puspitasari, (2010), Nugroho (2012), Farooq \& Masood (2016) menyatakan bahwa leverage berpengaruh positif dan signifikan terhadap nilai perusahaan. Herawati (2011) juga menemukan bahwa kebijakan utang (leverage) berpengaruh positif dan tidak signifikan terhadap nilai perusahaan.

Menurut Asadi \& Zendehdel (2014), Hunjra et al. (2014), dan Farrukh et al. (2017), adanya pengaruh positif signifikan dari dividen terhadap nilai perusahaan. Penelitian Wijaya \& Wibawa (2010), Priya \& Mohanasundari (2016), serta Budagaga (2017) juga menemukan bahwa kebijakan dividen berpengaruh positif terhadap nilai perusahaan. Adapun penelitian Abidin dkk. (2011) menemukan adanya pengaruh negatif signifikan dari kebijakan dividen terhadap nilai perusahaan. Egbeonu \& Edori (2018) menyatakan bahwa kebijakan dividen tidak berpengaruh terhadap nilai perusahaan.

Penelitian ini dilakukan pada sektor properti, real estate, dan konstruksi bangunan. Perkembangan sektor ini merupakan salah satu indikator pertumbuhan ekonomi sebuah negara. Investasi pada sektor ini merupakan investasi yang menjanjikan di masa yang akan datang dan menjadi pilihan yang aman bagi investor untuk berinvestasi (Wahyuni dkk., 2013). Prospek yang cerah ini tentunya tidak terlepas dari kebutuhan masyarakat yang menganggap properti sebagai bagian dari kebutuhan primer yang harus dipenuhi keberadannya (Rizal \& Sahar, 2012). 
Pembangunan tempat tinggal, gedung kantor, pusat perbelanjaan, tempat rekreasi, sekolah, dan lain-lain berlangsung secara terus-menerus dan berkembang mengikuti perkembangan jaman. Namun tetap saja, harga saham perusahaan sektor properti, real estate, dan konstruksi berfluktuasi karena adanya faktor-faktor respon dan reaksi dari investor yang berbeda dari setiap informasi yang terdapat di pasar.

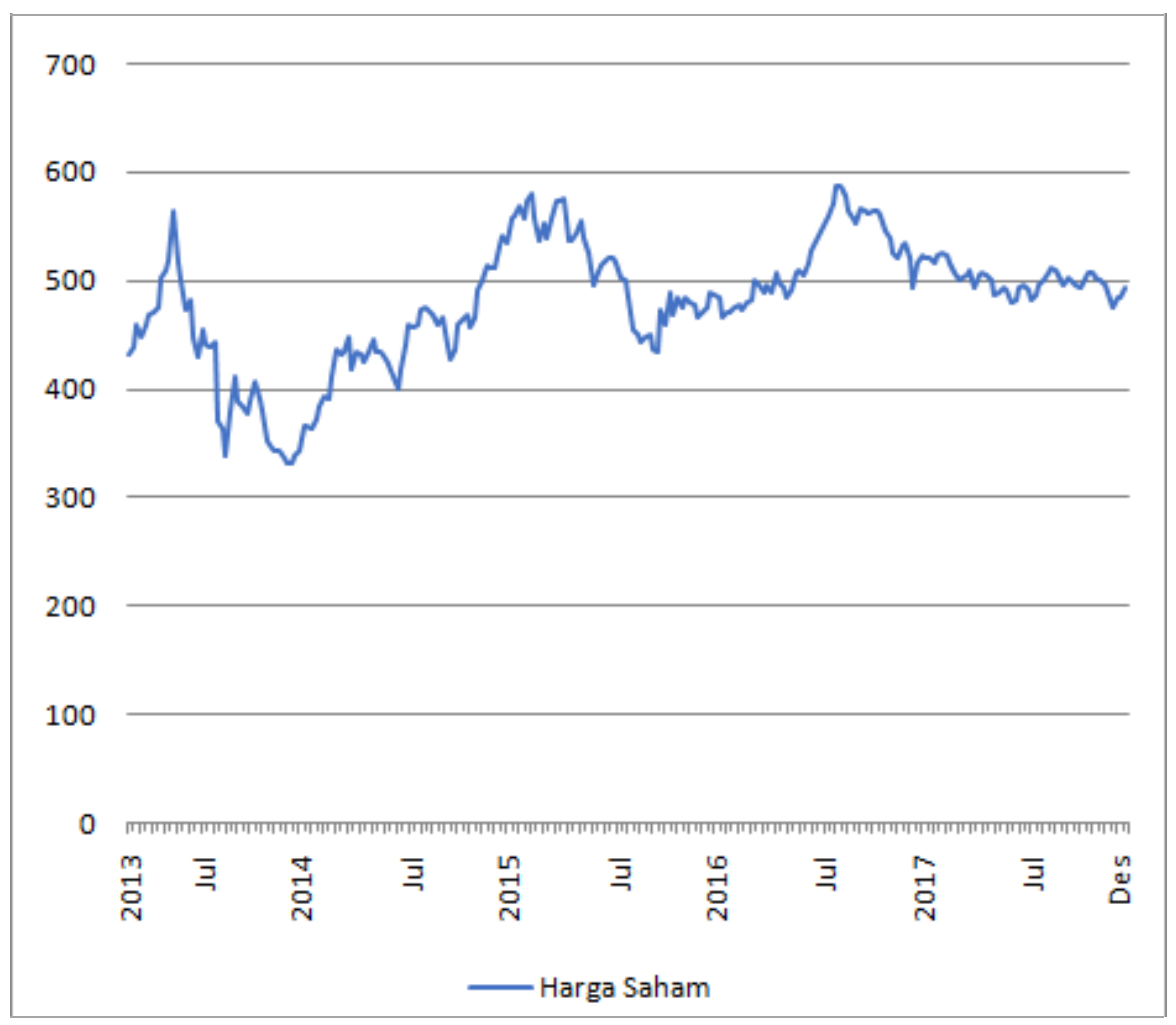

\section{Gambar 1. Grafik Perkembangan Harga saham sektor properti, real estate, dan konstruksi bangunan tahun 2014-2017 \\ Sumber: www.idx.co.id, data diolah}

Indeks sektor properti, real estate, dan konstruksi bangunan pada tahun 2014 mencapai indeks sektor 55,76 persen namun pada tahun 2015 menurun drastis mencapai angka minus 6,47 persen. Pada tahun 2016, indeks sektor properti, real estate dan konstruksi bangunan berhasil naik menjadi 18,7 persen dan kembali mengalami penurunan pada tahun 2017 hingga mencapai angka minus 4,31 persen. (www.investasi.kontan.co.id). Dari persentase peningkatan dan penurunan indeks sektor properti, real estate, dan konstruksi dapat diasumsikan bahwa harga saham perusahaan-perusahaan properti, real estate, dan konstruksi bangunan tahun 2014 - 2017 cukup berfluktuasi.

Pada sektor properti, real estate, dan konstruksi bangunan terdapat enam puluh sembilan (69) perusahaan yang terdaftar di Bursa Efek Indonesia yang masing - masing berlomba untuk membuat dan mengembangkan produk-produk properti, real estate, dan konstruksi bangunan yang baru. Semakin banyaknya 
produk - produk properti, real estate dan konstruksi bangunan yang baru dipasaran, berimbas pula pada fluktuasi penjualan produk masing-masing perusahaan yang mengakibatkan meningkatnya laba perusahaan sehingga berpengaruh terhadap harga saham dari tiap-tiap perusahaan. Dengan mengetahui rasio-rasio yang berpengaruh signifikan terhadap nilai perusahaan, maka hal ini dapat menjadi pertimbangan dasar keputusan bagi investor dalam mengambil keputusan untuk berinvestasi (Raipassa dkk., 2015).

Profitabilitas adalah kemampuan perusahaan untuk menghasilkan laba dari kegiatan operasionalnya. Makin tinggi laba, makin tinggi return yang diperoleh oleh investor. Tinggi rendahnya tingkat return yang mungkin diterima oleh investor biasanya mempengaruhi penilaian investor. Makin tinggi penilaian investor akan suatu saham, maka harga saham tersebut akan makin tinggi. Dana yang dibayarkan sebagai dividen adalah laba yang diperoleh dari hasil operasi perusahaan yang tersedia bagi pemegang saham (Husnan \& Pudjiastuti, 2012). Chen \& Chen (2011), Wulandari (2013), Wahyuni dkk. (2013), Mahendra dkk. (2009), Sabrin et al. (2016), Andawasatya et al. (2017), dan Tui et al. (2017) dalam penelitiannya menyatakan bahwa profitabilitas berpengaruh positif terhadap nilai perusahaan. Dengan demikian hipotesis yang dapat dibuat adalah:

$\mathrm{H}_{1}$ : Profitabilitas berpengaruh positif dan signifikan terhadap nilai perusahaan.

Hasibuan dkk. (2015) menyatakan bahwa perusahaan dengan rasio leverage yang rendah akan memiliki risiko kerugian yang kecil ketika keadaan ekonomi mengalami kemerosotan. Namun disaat kondisi ekonomi membaik, kesempatan dalam memperoleh laba juga rendah. Tidak menutup kemungkinan sebuah perusahaan yang memiliki rasio leverage yang besar tidak lebih bagus dibandingkan dengan perusahaan yang memiliki rasio leverage yang kecil karena terkadang hutang dibutuhkan. Hutang digunakan untuk mengendalikan penggunaan free cash flow secara berlebihan, sehingga dapat menghindari investasi yang siasia. Penggunaan utang akan meningkatkan nilai perusahaan, karena saat kebutuhan utangnya naik, biasanya digunakan untuk pembiayaan perusahaan. Peningkatan nilai tersebut dikaitkan dengan harga saham dan penurunan utang akan menurunkan harga saham. Namun demikian peningkatan utang juga akan menimbulkan peningkatan risiko kebangkrutan bila tidak diimbangi dengan penggunaan hutang yang hati - hati.

Penelitian yang dilakukan oleh Sudiyatno \& Puspitasari (2010), Nugroho 2012), Farooq \& Masood (2016) menyatakan bahwa leverage berpengaruh positif dan signifikan terhadap nilai perusahaan. Oleh karena itu hipotesis yang dapat dibangun adalah :

$\mathrm{H}_{2}$ : Leverage berpengaruh positif dan signifikan terhadap nilai perusahaan.

Dividen adalah laba bersih yang diperoleh perusahaan, oleh karena itu dividen akan dibagikan apabila perusahaan memperoleh keuntungan. Semakin besar dividen yang dibagi akan semakin meningkatkan nilai suatu perusahaan. Dividen adalah pembagian laba kepada para pemegang saham oleh perusahaan. Kebijakan dividen harus sesuai dengan kebutuhan perusahaan maupun kebutuhan para pemegang saham. Pada saat perusahaan mengalami pertumbuhan, dividen 
mungkin kecil karena lebih memusatkan kegiatan menumpuk dana, akan tetapi pada saat sudah berada pada masa maturity (penerimaan yang diperoleh sudah cukup besar), sementara kebutuhan pemupukan dana tidak begitu besar, maka dividen yang dibayarkan dapat diperbesar.

Dengan membayarkan dividen secara wajar, maka perusahaan dapat membantu menarik para investor untuk mencari dividen dan hal ini dapat membantu memelihara nilai perusahaan. Hasil yang diharapkan oleh para investor adalah berupa dividen dan kenaikan nilai saham. Sebaliknya, ketika perusahaan menurunkan tingkat pembayaran dividennya, maka pasar menilai perusahaan sedang mengalami masalah keuangan jangka panjang (Asadi \& Zendehdel, 2014). Menurut Wijaya \& Wibawa (2010), Priya \& Mohanasundari (2016), serta Budagaga (2017) menemukan bahwa kebijakan dividen berpengaruh positif terhadap nilai perusahaan. Dengan demikian hipotesis yang dapat dibuat adalah:

$\mathrm{H}_{3}$ : Kebijakan dividen berpengaruh positif dan signifikan terhadap nilai perusahaan.

Berdasarkan latar belakang masalah serta kajian teoritis dan empiris yang telah dipaparkan sebelumnya, maka kerangka konseptual antara variabel dependen yaitu nilai perusahaan dengan variabel independen yaitu profitabilitas, leverage, dan kebijakan dividen disusun sebagai berikut:

\section{Variabel Independen Variabel Dependen}

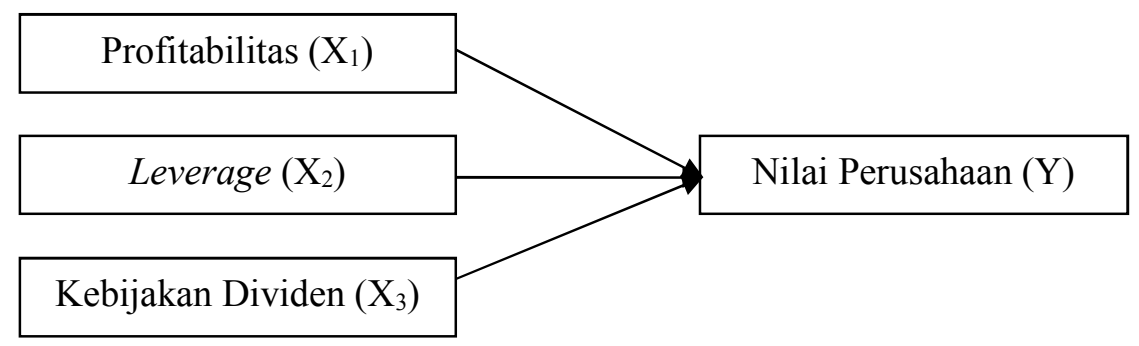

Gambar 1. Kerangka Konseptual

Sumber : diolah untuk penelitian

\section{METODE PENELITIAN}

Penelitian ini dilakukan pada perusahaan perusahaan sektor properti, real estate, dan konstruksi bangunan yang terdaftar di Bursa Efek Indonesia (BEI) pada tahun 2014 - 2017 dengan mengakses data melalui situs resmi BEI.

Nilai perusahaan dalam penelitian ini menggunakan rasio Price to book Value dalam satuan kali, yaitu :

$$
\mathrm{PBV}=\frac{\text { Harga per Lembar Saham }}{\text { Nilai Buku per Lembar Saham }} .
$$


Profitabilitas dalam penelitian ini menggunakan rasio Return on Equity (ROE) dalam satuan persen (\%), yaitu :

$$
R O E=\frac{\text { Net Income }}{\text { Total Equity }} 100 \%
$$

Leverage dalam penelitian ini menggunakan Debt to Equity Ratio (DER) dalam satuan persen $(\%)$, yaitu:

$$
D E R=\frac{\text { Total Hutang }}{\text { Total Modal }}
$$

Kebijakan dividen dalam penelitian ini menggunakan rasio Dividend Payout Ratio dalam satuan persen (\%), yaitu :

$$
D P R=\frac{\text { Dividend per Share }}{\text { Earning per Share }} 100 \%
$$

Populasi penelitian ini adalah perusahaan properti, real estate, dan konstruksi bangunan di Bursa Efek Indonesia selama periode 2014 - 2017. Yaitu sebanyak 69 perusahaan.Sampel ditentukan dengan metode purposive sampling yang menentukan kriteria tertentu dalam menentukan sampel yang akan digunakan.

Berdasarkan kriteria yang telah disebutkan, maka dapat diperoleh jumlah sampel peneltian dengan rincian sebagai berikut:

Tabel 1.

Kriteria Penentuan Sampel

\begin{tabular}{clc}
\hline No & \multicolumn{1}{c}{ Keterangan } & $\begin{array}{c}\text { Jumlah } \\
\text { Perusahaan }\end{array}$ \\
\hline 1 & $\begin{array}{l}\text { Populasi Perusahaan Sektor Properti, Real Estate, dan Konstruksi } \\
\text { Bangunan di Bursa Efek Indonesia } \\
2\end{array}$ & $\begin{array}{l}\text { Perusahaan yang data keuangannya tidak tersedia di Bursa Efek } \\
\text { Indonesia }\end{array}$ \\
$\quad \begin{array}{l}\text { Perusahaan yang tidak membagikan dividen berturut-turut dari tahun } \\
\text { buku 2014 - 2017 }\end{array}$ & $(30)$ \\
4 & Total Perusahaan yang dijadikan Sampel & $\mathbf{1 9}$ \\
\hline Sumber: Data diolah, 2018
\end{tabular}

Dari populasi sebanyak enam puluh sembilan (69) perusahaan properti, real estate, dan konstruksi di Bursa Efek Indonesia, sembilan belas (19) perusahaan memenuhi kriteria yang telah disebutkan, namun enam (6) perusahaan merupakan data outlier dan hanya tersisa tiga belas (13) perusahaan yang akan dijadikan sampel penelitian.

Analisis model berganda dilakukan untuk mengetahui pengaruh antar variabel terikat dan variabel bebas dengan bantuan SPSS. Model regresi linear berganda ditunjukkan sebagai berikut :

$$
Y=\alpha+\beta_{1} X_{1}+\beta_{2} X_{2}+\beta_{3} X_{3}+e .
$$

Keterangan :

Y : Nilai Perusahaan 


$\begin{array}{ll}\alpha & \text { : Konstanta } \\ \mathrm{X}_{1} & \text { : Profitabilitas } \\ \mathrm{X}_{2} & \text { : Leverage } \\ \mathrm{X}_{3} & \text { : Kebijakan Dividen } \\ \beta_{1} & \text { : Koefisien regresi variabel } \mathrm{X}_{1} \\ \beta_{2} & \text { : Koefisien regresi variabel } \mathrm{X}_{2} \\ \beta_{3} & \text { : Koefisien regresi variabel } \mathrm{X}_{3} \\ \mathrm{e} & \text { : Standard error }\end{array}$

\section{HASIL DAN PEMBAHASAN}

Statistik deskriptif disajikan untuk informasi mengenai nilai minimum, nilai maksimum, nilai rata - rata (mean), dan nilai standar deviasi dari variabel penelitian. Hasil dari statistik deskriptif dapat dilihat pada Tabel 2 berikut.

Tabel 2.

Hasil Analisis Statistik Deskriptif

\begin{tabular}{lcccc}
\hline & PBV & ROE & DER & DPR \\
\hline$N$ & 52 & 52 & 52 & 52 \\
Mean & 1,97346 & 12,86904 & 1,24578 & 0,21430 \\
Minimum & 0,430 & 0,840 & 0,060 & 0,029 \\
Maximum & 4,790 & 31,380 & 4,971 & 0,713 \\
Standard Deviation & 1,192507 & 6,693574 & 0,915489 & 0,158088 \\
\hline
\end{tabular}

Sumber : Data diolah, 2018

Berdasarkan Tabel 2. dapat dilihat jumlah pengamatan $(\mathrm{N})$ dalam penelitian ini sebanyak 52. Skor minimum dalam tabel menunjukkan nilai terendah dari data penelitian, sedangkan skor maksimum dalam tabel menunjukkan nilai tertinggi dari data penelitian. Mean digunakan untuk mengukur nilai rata - rata dari data., dan standard deviation menunjukkan simpangan baku.

$P B V$ dari 52 sampel mempunyai rentang nilai dari 0,43 sampai 4,79 kali. Nilai terendah 0,43 kali dimiliki oleh perusahaan Perdana Gapuraprima Tbk pada tahun 2017 dan nilai tertinggi sebesar 4,79 kali dimiliki oleh perusahaan Wijaya Karya (Persero) Tbk pada tahun 2014. Nilai rata - rata $P B V$ sebesar 1,973 dengan standar deviasi sebesar 1,193.

$R O E$ dari 52 sampel mempunyai rentang nilai dari 0,84 sampai 31,38. Nilai terendah sebesar 0,84 dimiliki oleh perusahaan Bumi Serpong Damai Tbk pada tahun 2016 dan nilai tertinggi sebesar 31,38 dimiliki oleh perusahaan Pakuwon Jati Tbk pada tahun 2014. Nilai rata - rata $R O E$ sebesar 12,869 dengan standar deviasi sebesar 6,694.

DER dari 52 sampel mempunyai rentang nilai dari 0,06 sampai 4,97. Nilai terendah sebesar 0,06 dimiliki oleh perusahaan Bumi Serpong Damai Tbk pada tahun 2015 dan nilai tertinggi sebesar 4,97 dimiliki oleh perusahaan Adhi Karya (Persero) Tbk pada tahun 2014. Nilai rata - rata DER sebesar 1,246 dengan standar deviasi sebesar 0,915 .

DPR dari 52 sampel mempunyai rentang nilai dari 0,03 sampai 0,71. Nilai terendah sebesar 0,03 dimiliki oleh perusahaan Bekasi Fajar Industrial Estate pada tahun 2014 dan nilai tertinggi sebesar 0,71 dimiliki oleh perusahaan Total Bangun 
Persada Tbk pada tahun 2016. Nilai rata - rata DPR sebesar 0,214 dengan standar deviasi sebesar 0,158 .

Regresi linier berganda digunakan untuk mengetahui arah dan besarnya pengaruh profitabilitas, leverage, dan kebijakan dividen terhadap nilai perusahaan sektor property, real estate dan konstruksi bangunan di BEI tahun 2014 - 2017 dengan menggunakan SPSS. Hasil regresi linier berganda untuk penelitian ini dapat dilihat pada Tabel 3 berikut.

Tabel 3.

Hasil Analisis Regresi Linier Berganda

\begin{tabular}{cccc}
\hline No. & Variabel & Koefisien Regresi & Sig. \\
\hline & (Constant) & 0,051 & 0,860 \\
1. & ROE & 0,118 & 0,000 \\
3. & DER & 0,420 & 0,007 \\
R Square $=0,532$ & DPR & $-0,531$ & 0,594 \\
Adjusted R Square $=0,503$ & & & $\mathrm{~F}=18,198$ \\
\hline
\end{tabular}

Sumber: Data diolah, 2018

Berdasarkan Tabel 3. maka dapat dibentuk persamaan regresi linier berganda pada penelitian ini yaitu sebagai berikut :

$$
\mathrm{Y}=0,051+0,118 \mathrm{X}_{1}+0,420 \mathrm{X}_{2}-0,531 \mathrm{X}_{3}
$$

Keterangan :

$\mathrm{Y}=$ Nilai Perusahaan

$\mathrm{X}_{1}=$ Profitabilitas

$\mathrm{X}_{2}=$ Leverage

$\mathrm{X}_{3}=$ Kebijakan Dividen

Koefisien profitabilitas (ROE) sebesar 0,118 memiliki arti bahwa, jika profitabilitas (ROE) bertambah 1 satuan maka nilai perusahaan akan meningkat sebesar 0,118 kali dengan asumsi variabel lainnya konstan.

Koefisien leverage (DER) sebesar 0,420 memiliki arti bahwa, jika leverage meningkat sebesar 1 satuan, maka nilai perusahaan akan meningkat sebesar 0,420 kali dengan asumsi variabel lainnya konstan.

Koefisien kebijakan dividen (DPR) sebesar -0,531 memiliki arti bahwa jika kebijakan dividen (DPR) meningkat sebesar 1 satuan, maka nilai perusahaan akan mengalami penurunan sebesar 0,531 kali dengan asumsi variabel lainnya konstan.

Model regresi yang baik akan berdistribusi normal. Residual berdistribusi normal apabila Asymp. Sig (2-tailed) menunjukkan nilai yang lebih besar dari 0,05. Hasil uji normalitas pada Tabel 4 berikut merupakan pengujian terhadap 76 data pengamatan (19 perusahaan).

Berdasarkan Tabel 4. hasil pengujian normalitas Unstandardized Residual tidak berdistribusi normal karena nilai signifikansinya $0,000<0,05$. Hal ini berarti data tidak berdistribusi normal. Untuk memperoleh data yang berdistribusi normal, maka dilakukanlah uji outlier. 
Tabel 4.

Hasil Uji Normalitas I

\begin{tabular}{lrr}
\hline & & \\
\hline$N$ & & Unstandardized Residual \\
Normal Parameter, & Mean & 76 \\
& Std Deviation & 0,0000000 \\
Most Extreme & Absolute & 1,86082551 \\
Differences & Positive & 0,186 \\
& Negative & 0,186 \\
Kolmogorov-Smirnov $Z$ & & $-0,082$ \\
Asymp. Dig. (2-tailed) & & 0,186 \\
Sumber: Data diolah, 2018 & 0,000 \\
\hline
\end{tabular}

Uji outlier adalah data yang memiliki karakteristik unik yang terlihat sangat berbeda jauh dari observasi-observasi lainnya dan muncul dalam bentuk nilai ekstrim baik untuk sebuah variabel tunggal atau variabel kombinasi. Setelah data outlier dihilangkan, maka data yang semula sebanyak 76 data menjadi 52 data (13 perusahaan). Berikut adalah hasil uji normalitas kedua.

Tabel 5.

Hasil Uji Normalitas II

\begin{tabular}{llr}
\hline & & Unstandardized Residual \\
\hline$N$ & & 52 \\
Normal Parameter & Mean & 0,0000000 \\
& Std Deviation & 0,81567922 \\
Most Extreme & Absolute & 0,105 \\
Differences & Positive & 0,105 \\
& Negative & $-0,059$ \\
Kolmogorov-Smirnov $Z$ & & 0,759 \\
Asymp. Dig. (2-tailed) & & 0,612 \\
\hline
\end{tabular}

Sumber: Data diolah, 2018

Berdasarkan Tabel 5. hasil pengujian secara statistik memperoleh nilai Asymp. Sig (2-tailed) sebesar 0,612 yang mana memiliki nilai lebih besar dari 0,05. Hal ini berarti bahwa regresi berdistribusi normal.

Uji multikolinearitas bertujuan untuk mendeteksi hal tersebut maka dapat dilihat pada nilai tolerance dan nilai variance inflation factor (VIF). Uji multikoloniaritas bertujuan untuk menguji apakah pada model regresi ditemukan adanya korelasi antar variabel independen.

Model regresi dikatakan baik jika tidak ditemukannya multikolonearitas atau tidak terjadi korelasi antar variabel independen dapat dilihat dari nilai tolerance dan nilai Variance Inflation Factor (VIF). Jika nilai tolerance diatas $10 \%$ atau VIF dibawah 10, maka dikatakan tidak ada multikolonearitas.

Berdasarkan Tabel 6. memperlihatkan hasil tolerance dan VIF masing masing variabel yang memiliki nilai tolerance diatas 10 persen dan nilai VIF dibawah 10. Berdasarkan hasil tersebut maka dapat disimpulkan bahwa model regresi dalam penelitian ini tidak mengandung gejala multikolinearitas dan layak digunakan untuk memprediksi. 
Tabel 6.

Hasil Uji Multikolinearitas

\begin{tabular}{cccc}
\hline No. & Variabel & Tolerance & VIF \\
\hline 1. & ROE & 0,723 & 1,383 \\
2. & DER & 0,753 & 1,328 \\
3. & DPR & 0,567 & 1,764 \\
\hline
\end{tabular}

Sumber: Data diolah, 2018

Uji autokorelasi berfungsi untuk memperlihatkan pengaruh data dari pengamatan sebelumnya dalam model regresi. Hasil pengujian akan membantu memprediksi apakah model itu bias atau dapat memberikan hasil prediksi yang menyimpang.

Uji autokorelasi dapat dilakukan dengan menggunakan Uji Durbin-Watson (DW-test). Model regresi yang baik tidak akan mengandung gejala autokorelasi. Model regresi tidak mengandung gejala autokorelasi dengan kriteria $d_{u}<d<4-d_{u}$.

Tabel 7.

Hasil Uji Autokorelasi

\begin{tabular}{cccccc}
\hline Model & R & R Square & $\begin{array}{c}\text { Adjusted } \\
\text { R Square }\end{array}$ & $\begin{array}{c}\text { Std. Error of } \\
\text { the Estimate }\end{array}$ & $\begin{array}{c}\text { Durbin- } \\
\text { Watson }\end{array}$ \\
\hline 1 & $0,729^{\text {a }}$ & 0,532 & 0,503 & 0,840783 & 1,998 \\
\hline
\end{tabular}

Sumber: Data diolah, 2018

Berdasarkan Tabel 7. memperlihatkan hasil Durbin-Watson yang diperoleh sebesar 1,998. Model regresi tidak mengandung gejala autokorelasi dengan kriteria $\mathrm{d}_{\mathrm{u}}<\mathrm{d}<4-\mathrm{d}_{\mathrm{u}}$. Pada penelitian ini diperoleh nilai $\mathrm{dL}=1,43, \mathrm{~d}_{\mathrm{u}}=1,68$ dan $4-\mathrm{d}_{\mathrm{u}}=$ maka $1,68<1,99<2,32$. Ini berarti model regresi bebas dari gejala autokorelasi sehingga layak untuk memprediksi.

Uji heteroskedastisitas dapat dilakukan dengan metode glejser dimana meregresi variabel bebas terhadap absolut-residual. Apabila variabel bebas dalam penelitian tidak memiliki pengaruh yang signifikan terhadap residual absolut maka model regresi tidak mengandung gejala heteroskedastisitas.Hasil uji heteroskedastisitas disajikan pada Tabel 8 . berikut.

Tabel 8.

Hasil Uji Heteroskedastisitas

\begin{tabular}{ccccccc}
\hline & & \multicolumn{2}{c}{$\begin{array}{c}\text { Unstandardized } \\
\text { Coefficients }\end{array}$} & $\begin{array}{c}\text { Standardized } \\
\text { Coefficients }\end{array}$ & & \\
& Model & B & Std. Error & Beta & t & Sig. \\
\hline 1 & (Constant) & 0,264 & 0,179 & & 1,476 & 0,147 \\
& ROE (X1) & 0,016 & 0,013 & 0,206 & 1,271 & 0,210 \\
& DER (X2) & 0,092 & 0,092 & 0,158 & 0,995 & 0,325 \\
& DPR (X3) & 0,106 & 0,617 & 0,032 & 0,172 & 0,864 \\
\hline
\end{tabular}

Sumber: Data diolah, 2018

Berdasarkan hasil pengujian secara statistik yang ditunjukkan pada Tabel 8 . diperoleh hasil uji heteroskedastisitas masing - masing variabel bebas yang memiliki nilai signifikan lebih dari 0,05 , sehingga dapat dikatakan bahwa model 
regresi bebas dari heteroskedastisitas dan layak digunakan untuk memprediksi lebih lanjut.

Koefisien determinasi $\left(\mathrm{R}^{2}\right)$ digunakan untuk mengukur seberapa jauh kemampuan model dalam menerangkan variasi variabel dependen. Nilai koefisien determinasi adalah antara nol dan satu. Tujuan penggunaan dari adjusted $\mathrm{R}^{2}$ adalah menggeneralisasikan $\mathrm{R}^{2}$ pada populasi, karena ada unsur estimasi populasi di dalamnya.

Penggunaan $\mathrm{R}^{2}$ ataupun adjusted $\mathrm{R}^{2}$ tergantung pada penelitian yang dilakukan. Jika penelitian yang dilakukan lebih mengarah pada penelitian populasi (pengambilan melalui random dari populasi yang ditetapkan), maka yang dipakai adalah adjusted $\mathrm{R}^{2}$, sedangkan apabila yang diteliti adalah individu yang dipilih dengan non-random maka individu yang diteliti disebut subjek atau partisipan, bukan sampel sehingga cukup menggunakan $\mathrm{R}^{2}$ saja karena tidak bertujuan untuk menggeneralisasikan ke populasi yang lebih luas.

\section{Tabel 9.}

Ringkasan Hasil Uji $\mathbf{R}^{2}$ (Koefisien Determinasi)

\begin{tabular}{|c|c|c|c|}
\hline Model & $\mathbf{R}$ & R Square & Adjusted R Square \\
\hline 1 & $0,729^{\mathrm{a}}$ & 0,532 & 0,503 \\
\hline
\end{tabular}

Sumber: Data diolah, 2018

Berdasarkan Tabel 9. memperlihatkan hasil adjusted $\mathrm{R}^{2}$ sebesar 0,503 yang memiliki arti bahwa sebesar 50,3 persen perubahan nilai perusahaan pada sektor properti, real estate dan konstruksi bangunan di Bursa Efek Indonesia periode 2014 - 2017 dipengaruhi oleh profitabilitas, leverage dan kebijakan dividen, sedangkan sisanya 49,7 persen dipengaruhi oleh variabel lain di luar model regresi.

Tabel 10.

Hasil Uji Kelayakan Model (Uji F)

\begin{tabular}{lllllll}
\hline Model & & Sum of & & & & \\
\hline 1 & Regression & 38,594 & 3 & 12,865 & 18,198 & 0,000 \\
& Residual & 33,932 & 48 & 0,707 & & \\
& Total & 72,526 & 52 & & & \\
\hline
\end{tabular}

Sumber: Data diolah, 2018

Berdasarkan Tabel 10. diketahui bahwa hasil uji kelayakan model (uji F) menunjukkan bahwa profitabilitas, leverage dan kebijakan dividen secara signifikan berpengaruh terhadap nilai perusahaan, dimana signifikansi $\mathrm{F}$ sebesar $0,000<0,05$ sehingga model penelitian ini layak untuk diteliti dan pembuktian hipotesis dapat dilanjutkan.

Uji t digunakan untuk menguji apakah tiap variabel independen berpengaruh signifikan terhadap variabel dependen. Uji ini dilakukan untuk menguji hipotesis yang menyatakan pengaruh profitabilitas, leverage, dan kebijakan dividen pada nilai perusahaan. 
Tabel 11.

Ringkasan Hasil Uji t

\begin{tabular}{lrrrrr}
\hline \multicolumn{7}{c}{$\begin{array}{c}\text { Unstandardized } \\
\text { Coefficients }\end{array}$} & \multicolumn{2}{c}{$\begin{array}{c}\text { Standardized } \\
\text { Coefficients }\end{array}$} \\
Model & \multicolumn{1}{c}{ B } & Std. Error & \multicolumn{1}{c}{ Beta } & t & Sig. \\
\hline $1 \quad$ (Constant) & 0,051 & 0,287 & & 0,177 & 0,860 \\
ROE & 0,118 & 0,021 & 0,660 & 5,687 & 0,000 \\
DER & 0,420 & 0,148 & 0,322 & 2,832 & 0,007 \\
DPR & $-0,531$ & 0,989 & $-0,070$ & $-0,536$ & 0,594 \\
\hline
\end{tabular}

Sumber: Data diolah, 2018

Berdasarkan Tabel 11. pengaruh variabel profitabilitas terhadap nilai perusahaan ditemukan Sig.t $=0,000<$ taraf signifikansi $(\alpha)=0,05$, maka $\mathrm{H}_{0}$ ditolak atau $\mathrm{H}_{1}$ diterima, ini berarti profitabilitas berpengaruh positif dan signifikan terhadap nilai perusahaan sektor properti, real estate dan konstruksi bangunan di Bursa Efek Indonesia periode 2014 - 2017.

Untuk pengaruh variabel leverage terhadap nilai perusahaan ditemukan Sig.t $=0,007<$ taraf signifikansi $(\alpha)=0,05$, maka $\mathrm{H}_{0}$ ditolak atau $\mathrm{H}_{2}$ diterima, ini berarti leverage berpengaruh positif dan signifikan terhadap nilai perusahaan sektor properti, real estate dan konstruksi bangunan di Bursa Efek Indonesia periode 2014 $-2017$.

Untuk pengaruh variabel kebijakan dividen terhadap nilai perusahaan ditemukan Sig.t $=0,594>$ taraf signifikansi $(\alpha)=0,05$, maka $\mathrm{H}_{0}$ diterima atau $\mathrm{H}_{3}$ ditolak, ini berarti kebijakan dividen berpengaruh negatif dan tidak signifikan terhadap nilai perusahaan sektor properti, real estate dan konstruksi bangunan di Bursa Efek Indonesia periode 2014 - 2017.

Uji regresi (t-test) ini juga untuk mengetahui variabel mana yang pengaruhnya paling dominan terhadap nilai perusahaan sektor properti, real estate dan konstruksi bangunan di Bursa Efek Indonesia periode 2014 - 2017. Dilihat dari Standardized Coefficients Beta variabel bebas yang berpengaruh signifikan terhadap variabel terikat. Berdasarkan Tabel 4.8 terlihat bahwa Standardized Coefficients Beta yang terbesar adalah variabel bebas profitabilitas (ROE), yaitu sebesar 0,660 yang berarti profitabilitas berpengaruh dominan terhadap nilai perusahaan, yaitu sebesar 66 persen pada sektor properti, real estate dan konstruksi bangunan di Bursa Efek Indonesia periode 2014 - 2017.

Hasil pengujian menunjukkan variabel profitabilitas yang diproksikan dengan ROE menunjukkan tingkat signifikan profitabilitas sebesar $0,000(<0,05)$ dan koefisien regresi 0,118 . Hasil ini menunjukkan bahwa hipotesis diterima yaitu profitabilitas berpengaruh positif dan signifikan terhadap nilai perusahaan. ROE dapat mempengaruhi PBV pada perusahaan sektor sektor properti, real estate, dan konstruksi bangunan. Semakin tinggi ROE menunjukkan tingkat efisien perusahaan dalam memperoleh laba juga tinggi sehingga PBV perusahaan meningkat.

Tingginya profitabilitas dapat menarik investor untuk berinvestasi pada sebuah perusahaan. Profitabilitas perusahaan yang tinggi menunjukkan bahwa perusahaan tersebut mampu menggunakan sumber daya yang dimiliki perusahaan untuk memperoleh laba yang efektif. Hal ini mampu meyakinkan investor bahwa 
perusahaan mampu meningkatkan kemakmuran para pemegang saham dengan dibagikannya return melalui dividen, sehingga investor tertarik untuk membeli saham perusahaan. Meningkatnya permintaan terhadap saham menyebabkan harga saham naik. Harga saham yang naik akan berdampak pada naiknya nilai perusahaan, dengan demikian naiknya profitabilitas dapat menjadi sinyal positif bagi investor.

Berdasarkan signaling theory, sebuah perusahaan dengan sukarela akan melaporkan informasi ke pasar modal tanpa adanya dorongan dari pemerintah, informasi ini ditujukan untuk mempertahankan minat dari investor agar tidak terjadi asimetri informasi antara pihak perusahaan dengan luar perusahaan (Brigham \& Houston, 2015:186). Penyampaian informasi mengenai profitabilitas suatu perusahaan merupakan sebuah sinyal bagi perusahaan. Profitabilitas yang tinggi dan stabil akan menjadi sinyal positif bagi investor terkait dengan kinerja perusahaan (Rizqia et al., 2013). Hasil ini didukung dengan penelitian Wahyuni dkk. (2013) yang menyatakan bahwa profitabilitas berpengaruh positif terhadap nilai perusahaan. Begitu pula penelitian yang dilakukan oleh Nurhayati (2018) dan Putu et al. (2014) yang memperoleh bukti bahwa kenaikan laba yang diperoleh perusahaan dapat meningkatkan nilai sebuah perusahaan.

Hasil pengujian hipotesis menunjukkan penerimaan atas hipotesis kedua yaitu $\mathrm{H}_{2}$ : leverage berpengaruh positif dan signifikan terhadap nilai perusahaan. Hasil penelitian ini mendukung teori sinyal yang menyatakan bahwa peningkatan leverage bisa memberikan dua macam sinyal, yaitu berita baik (good news) sekaligus berita buruk (bad news). Berdasarkan hasil penelitian dapat diketahui bahwa peningkatan rasio leverage dalam hal ini cenderung mengarah kepada berita baik karena peningkatan hutang tersebut merefleksikan kemampuan manajemen untuk meningkatkan nilai perusahaan. Apabila sinyal baik tersebut diterima maka perusahaan dianggap mampu menunjukkan kualitas perusahaan yang baik dan ketidakpastian investor untuk berinvestasi pada perusahaan tersebut akan berkurang. Hasil temuan ini didukung oleh penelitian terdahulu yang dilakukan oleh Farooq \& Masood (2016) yang menyatakan bahwa leverage berpengaruh positif dan signifikan terhadap nilai perusahaan, semakin tinggi proporsi hutang maka akan semakin tinggi nilai perusahaan dikarenakan pengelolaan yang baik terhadap hutang tersebut, namun pada titik tertentu peningkatan hutang akan menurunkan nilai perusahaan karena manfaat yang diperoleh dari penggunaan hutang hutang lebih kecil dari biaya yang ditimbulkan.

Hasil penelitian ini didukung penelitian yang dilakukan oleh Kusumajaya (2011), Analisa \& Wahyudi (2008) serta Cheng \& Tzeng (2014) yang menemukan bahwa leverage berpengaruh secara positif dan signifikan terhadap nilai perusahaan.

Hasil penelitian menunjukkan variabel kebijakan dividen yang diproksikan dengan $D P R$ mempunyai probabilitas tingkat signifikansi sebesar $0,594(>0,05)$ dan koefisien regresi sebesar $-0,531$. Hal ini menunjukkan bahwa kebijakan dividen berpengaruh negatif dan tidak signifikan terhadap $P B V$ perusahaan sektor properti, real estate dan konstruksi bangunan yang terdaftar di BEI periode 2014 - 2017, sehingga hipotesis ketiga ini ditolak. Hal ini menunjukkan bahwa kenaikan dividen yang akan dibagikan tidak diikuti dengan naiknya $P B V$ perusahaan, sehingga 
kebijakan dividen bukan merupakan faktor bagi investor dalam melakukan investasi. Hasil ini sejalan dengan penelitian sebelumnya yang dilakukan oleh Abidin dkk. (2011) dan Egbeonu \& Edori (2018) menyatakan bahwa kebijakan dividen tidak berpengaruh terhadap nilai perusahaan.

Berdasarkan hasil penelitian, tinggi rendahnya dividen yang dibagikan tidak mampu mempengaruhi nilai perusahaan. Kebijakan dividen bukan menjadi faktor utama bagi investor dalam menilai suatu perusahaan. Semakin tinggi dividen yang dibagikan tidak menjamin nilai perusahaan juga akan meningkat. Kebijakan dividen perusahaan belum dapat menjamin bahwa dengan membagikan dividen yang tinggi dapat membuat kemakmuran pemegang saham menjadi meningkat, karena pihak internal perusahaan belum dapat menjamin dengan dividen yang besar akan menghasillkan keuntungan maksimal yang diharapkan investor. Menurut Suwardika \& Mustanda (2017), investor lebih melihat aspek - aspek seperti kinerja perusahaan yang terlihat pada laporan keuangan perusahaan, dan nama baik perusahaan sebelum memutuskan untuk menanamkan dananya pada perusahaan tersebut.

Hasil penelitian ini sesuai dengan tax preference theory and clientele effect. Teori ini dilatarbelakangi oleh perbedaan pajak antara dividen dengan capital gain serta perbedaan pengenaan pajak bagi setiap investor. Investor dengan pajak yang tinggi akan cenderung menyukai pembagian dividen yang rendah.

Penelitian ini membahas mengenai pengaruh profitabilitas, leverage dan kebijakan dividen terhadap nilai perusahaan. Penelitian ini untuk mengetahui pengaruh dari ketiga variabel tersebut terhadap nilai suatu perusahaan. Hasil penelitian menunjukkan bahwa profitabilitas dan leverage berpengaruh signifikan terhadap nilai perusahaan, sedangkan kebijakan dividen tidak berpengaruh signifikan. Hasil menunjukkan bahwa profitabilitas dan leverage merupakan hal yang diperhatikan oleh investor sebelum berinvestasi.

Variabel pertama adalah profitabilitas yang diproksikan dengan $R O E$ memiliki pengaruh positif dan signifikan terhadap nilai perusahaan. Profitabilitas merupakan indicator yang dapat digunakan untuk menunjukkan efektifitas suatu perusahaan dan memperlihatkan bagaimana manajemen perusahaan mengelola sumber daya yang dimiliki. Semakin tinggi profitabilitas suatu perusahaan memberikan sinyal positif kepada investor bahwa perusahaan tersebut mengoptimalkan sumber daya yang dimiliki dalam menghasilkan laba serta menunjukkan kemampuan untuk meningkatkan kemakmuran para pemegang saham. Sinyal positif tersebut dapat membuat meningkatnya permintaan terhadap saham suatu perusahaan dan berdampak pada meningkatnya nilai suatu perusahaan.

Variabel kedua adalah leverage, peningkatan hutang perusahaan merefleksikan kemampuan manajemen untuk meningkatkan nilai. Apabila sinyal baik tersebut diterima maka perusahaan dianggap mampu menunjukkan kualitas perusahaan yang baik dan ketidakpastian investor untuk berinvestasi pada perusahaan tersebut akan berkurang.

Manajemen perusahaan harus memperhatikan $R O E$ dan $D E R$ serta faktor yang dapat mempengaruhi $R O E$ yaitu laba bersih dan total ekuitas, serta faktor yang membengaruhi $D E R$ yaitu total utang dan total modal sendiri untuk meningkatkan $P B V$ perusahaan. $R O E$ yang tinggi menunjukkan tingginya kemampuan perusahaan 
memperoleh laba dengan sumber daya yang dimiliki dan dengan $D E R$ yang tinggi menunjukkan kualitas perusahaan yang baik sehingga dapat menjadi sinyal bagi investor untuk membeli saham perusahaan yang menyebabkan meningkatnya nilai perusahaan.

\section{SIMPULAN DAN SARAN}

Berdasarkan hasil analisis dan pembahasan yang telah dilakukan pada bab sebelumnya, maka dapat disimpulkan bahwa meningkatnya profitabilitas menyebabkan nilai perusahaan naik menunjukkan profitabilitas memberikan sinyal positif kepada investor dan menjadi faktor yang harus diperhatikan oleh manajemen perusahaan. Pengelolaan yang baik terhadap hutang memberikan good news bagi investor karena semakin tinggi proporsi hutang maka akan semakin tinggi nilai perusahaan. Kebijakan dividen tidak diikuti dengan perubahan nilai perusahaan menunjukkan kebijakan dividen tidak dapat memberikan sinyal kepada investor.

Bagi pihak investor dan perusahaan diharapkan untuk lebih memperhatikan faktor -faktor yang berdampak bagi nilai perusahaan yaitu profitabilitas dan leverage. Hal ini dikarenakan profitabilitas dan leverage berpengaruh signifikan terhadap nilai perusahaan sehingga dapat memberikan sinyal posiif kepada investor. Bagi peneliti selanjutnya, dapat meneliti kembali pengaruh ketiga variabel tersebut terhadap nilai perusahaan dan juga ditambah dengan variabel lain yang dapat mempengaruhi nilai perusahaan seperti ukuran perusahaan, aktiva tidak berwujud, dan likuiditas, serta dapat menambah periode waktu penelitian agar dapat memperoleh hasil yang lebih baik.

\section{REFERENSI}

Abidin, Z., Yusniar, M. W., \& Ziyad, M. (2011). Pengaruh Struktur Modal, Kebijakan Dividen dan Size Terhadap Nilai Perusahaan ( Studi Pada Perusahaan Properti Di Bursa Efek Indonesia). Jurnal Wawasan Manajemen, 2(3), 91-102.

Adenugba, A. A., Ige, A. A., \& Kensiro, O. R. (2016). Financial Leverage and Firms' Value: A Study Of Selected Firms In Nigeria. European Journal of Research and Reflection in Management Sciences, 4(1), 14-32.

Analisa, Y., \& Wahyudi, S. (2008). Pengaruh Ukuran Perusahaan, Leverage ,Profitabilitas dan Kebijakan Dividen terhadap Nilai Perusahaan ( Studi Pada Perusahaan Manufaktur Yang Terdaftar Di Bursa Efek Indonesia). Undip EJournal System Portal Universitas Diponegoro, (2), 1-28.

Andawasatya, R. R., Indrawati, N. K., \& Aisjah, S. (2017). The Effect of Growth Opportunity, Profitability, Firm Size to Firm Value through Capital Structure (Study at Manufacturing Companies Listed On the Indonesian Stock Exchange). Imperial Journal of Interdisciplinary Resarch (IJIR), 3(2), 18871894.

Asadi, A., \& Zendehdel, A. (2014). Signalling Effects Of Dividend Announcements In Tehran Stock Exchange ( TSE ). Indian Journal of Commerce \& Management Studies, 5(2), 62-72. 
Brigham, E. F., \& Houston, J. F. (2011). Dasar-dasar Manajemen Keuangan (Edisi Sepuluh). Jakarta: Salemba Empat.

Brigham, E. F. \& Houston, J. F. (2015). Dasar-dasar Manajemen Keuangan (Edisi Sebelas). Jakarta: Salemba Empat.

Budagaga, A. (2017). Dividend Payment and its Impact on the Value of Firms Listed on Istanbul Stock Exchange: A Residual Income Approach. International Journal of Economics and Financial Issues, 7(2), 370-376.

Chen, L., \& Chen, S. (2011). The Influence of Profitability on Firm Value with Capital Structure as The Mediator and Firm Size and Industry as Moderators. Investment Management and Financial Innovations, 8(3).

Cheng, M., \& Tzeng, Z. (2014). The Effect of Leverage on Firm Value and How The Firm Financial Quality Influence on This Effect. World Journal of Management, 3(2), 30-53.

Egbeonu, O. C., \& Edori, I. S. (2018). Effect of Dividend Policy on the Value of Firms (Emperical Study of Quoted Firms in Nigeria Stock Exchange). Research Journal of Finance and Accounting, 7(03), 17-24.

Farooq, M. A., \& Masood, A. (2016). Impact of Financial Leverage on Value of Firms : Evidence from Cement Sector of Pakistan. Research Journal of Finance and Accounting, 7(9), 73-77.

Farrukh, K., Irshad, S., Khakwani, M. S., Ishaque, S., \& Ansari, N. Y. (2017). Impact of Dividend Policy on Shareholders Wealth and Firm Performance in Pakistan. Cogent Business \& Management, 4(1408208), 1-11. https://doi.org/10.1080/23311975.2017.1408208

Gayatri, N. L. P. R., \& Mustanda, I. K. (2012). Pengaruh Struktur Modal , Kebijakan Dividen Dan Keputusan Investasi Terhadap Nilai Perusahaan. Jurnal Manajemen dan Kewirausahaan, 4(06), 1700-1718.

Hasibuan, V., Dzulkirom, M. A., \& Endang, W. N. (2015). Pengaruh Leverage dan Profitabilitas Terhadap Nilai Perusahaan ( Studi pada Perusahaan Property dan Real Estate yang Terdaftar di Bursa Efek Indonesia Periode Tahun 2012-2015 ). Jurnal Administrasi Bisnis (JAB), 39(1), 139-147.

Herawati, T. (2011). Pengaruh Kebijakan Dividen, Kebijakan Leverage dan Profitabilitas Terhadap Nilai Perusahaan. Jurnal Manajemen, 2(02), 1-18.

Hunjra, A. I., Ijaz, M. S., Chani, M. I., Hassan, S. ul, \& Mustafa, U. (2014). Impact of Dividend Policy, Earning per Share, Return on Equity, Profit after Tax on Stock Prices. International Journal of Economics and Empirical Research, 2(3), 109-115.

Ishari, M. P. S., \& Abeyrathna, S. P. G. M. (2016). The Impact of Financial Leverage on Firms ' Value ( Special Reference to Listed Manufacturing Companies in Sri Lanka). International Journal Of Advancement In Engineering Technology, Management and Applied Science (IJAETMAS), 3(07), 100-104.

Kusumajaya, D. K. O. (2011). Pengaruh Struktur Modal dan Pertumbuhan Perusahaan terhadap Profitabilitas dan Nilai Perusahaan pada Perusahaan Manufaktur di Bursa Efek Indonesia. Tesis. Fakultas Ekonomi Universitas Udayana, 1-132. 
Mahendra, A. D., Artini, L. G. S., \& Suarjaya, A. . G. (2009). Pengaruh Kinerja Keuangan Terhadap Nilai Perusahaan (Kebijakan Dividen Sebagai Variabel Moderating) Pada Perusahaan Manufaktur di Bursa Efek Indonesia. Jurnal Manajemen, Strategi Bisnis, dan Kewirausahaan, 6(2), 130-138.

Nugroho, W. A. (2012). Pengaruh Profitabilitas, Likuiditas, dan Leverage Terhadap Nilai Perusahaan. Artikel Publikasi Universitas Muhamadiyah Surakarta tahun 2012.

Nurhayati, M. (2018). Profitabilitas, Likuiditas, dan Ukuran Perusahaan Pengaruhnya Terhadap Kebijakan Dividend dan Nilai Perusahaan Sektor Jasa. Jurnal Keuangan dan Bisnis, 5(2), 144-153

Pratama, I. A., \& Wiksuana, I. (2018). Pengaruh Firm Size dan Profitabilitas terhadap Nilai Perusahaan dengan Struktur Modal Sebagai Variabel Mediasi. E-Jurnal Ekonomi dan Bisnis Universitas Udayana, 7(5), 1289-1318.

Priya, P. V., \& Mohanasundari, M. (2016). Dividend Policy and Its Impact on Firm Value: A Review of Theories and Empirical Evidence. Journal of Management Sciences and Technology, 3(03), 59-69.

Putu, N. N. G. M., Moeljadi, Djumahir, \& Djazuli, A. (2014). Factors Affecting Firm Value of Indonesia Public Manufacturing Firm. International Journal of Business and Management Invention, 3(2), 35-44.

Raipassa, C., Parengkuan, T., \& Saerang, I. (2015). Pengaruh Rasio Profitabilitas, Likuiditas, dan Leverage Terhadap Dividen Payout Ratio pada Perusahaan Farmasi yang Terdaftar Di Bursa Efek Indonesia. Jurnal Berkala Ilmiah Efisiensi, 15(05), 610-621.

Rizal, \& Sahar, S. (2012). Pengaruh Rasio Keuangan Terhadap Harga Saham Sektor Properti dan Real Estate pada bursa Efek Indonesia. Jurnal Binis dan Komunikasi KALBISocio, 2(1), 41-51.

Rizqia, D. A., Aisjah, S., \& Sumiati. (2013). Effect of Managerial Ownership, Financial Leverage, Profitability, Firm Size, and Investment Opportunity on Dividend Policy and Firm Value. Research Journal of Finance and Accounting, 4(11), 120-130.

Sabrin, Sarita, B., S, D. T., \& Sujono. (2016). The Effect of Profitability on Firm Value in Manufacturing Company at Indonesia Stock Exchange. The International Journal Of Engineering And Science (IJES), 5(10), 81-89.

Sambora, M. N., Handayani, S. R., \& Rahayu, S. M. (2014). Pengaruh Leverage Dan Profitabilitas Terhadap Nilai Perusahaan ( Studi Pada Perusahaan Food And Beverages Yang Terdaftar Di BEI. Jurnal Administrasi Bisnis (JAB), $8(1)$.

Sudiyatno, B., \& Puspitasari, E. (2010). Pengaruh Kebijakan Perusahaan Terhadap Nilai Perusahaan dengan Kinerja Perusahaan Sebagai Variabel Intervening (Studi Pada Perusahaan Manufaktur di Bursa Efek Indonesia). Jurnal Dinamika Keuangandan Perbankan, 2(1), 1-22.

Suwardika, I. N. A., \& Mustanda, I. K. (2017). Pengaruh Leverage, Ukuran Perusahaan, Pertumbuhan Perusahaan dan Profitabilitas Terhadap Nilai Perusahaan pada Perusahaan Properti. E-Jurnal Manajemen Universitas Udayana, 6(3), 1248-1277. 
Tui, S., Nurnajamuddin, M., Sufri, M., \& Nirwana, A. (2017). Determinants of Profitability and Firm Value: Evidence from Indonesian Banks. IRAInternational Journal of Management \& Social Sciences, 7(01), 84-95.

Wahyuni, T., Ernawati, E., \& Murhadi, W. R. (2013). Faktor-Faktor yang Mempengaruhi Nilai Perusahaan Sektor Property, Real Estate dan Building Construction di Bursa Efek Indonesia Periode 2008-2012. Jurnal Ilmiah Mahasiswa Universitas Surabaya, 2(01), 1-18.

Wijaya, L. R. P., \& Wibawa, B. A. (2010). Pengaruh Keputusan Investasi, Keputusan Pendanaan, Dan Kebijakan Dividen Terhadap Nilai Perusahaan. Simposium Nasional Akuntansi XIII Purwokerto. 1-21.

Wulandari, D. R. (2013). Pengaruh Profitabilitas, Operating Leverage, Likuiditas Terhadap Nilai Perusahaan Dengan Struktur Modal Sebagai Intervening. Accounting Analysis Journal Universitas Negeri Semarang, 2(4), 455-463. 